\title{
Politics without Politics
}

\section{Jodi Dean}

\section{I.}

In some left political theory, democracy is an aspiration that occupies a place once held by communism. One might think of Chantal Mouffe’s and Ernesto Laclau’s work on radical democracy, accounts of deliberative democracy influenced by Jürgen Habermas's theory of communicative action, or the pluralism espoused by William Connolly. These proper names,

however, point to more than the specific proposals of specific theorists. They highlight a general underlying supposition that despite all our problems with democracy, democracy is the solution to all our problems. Whether expressed as the idea of an empty place where things can be otherwise or in terms of a set of procedures that incorporate already the keys to revising and reforming political practice, democracy, it seems, is our only political option. As Margaret Thatcher said of capitalism, there is no alternative. For the left, democracy is our last, best hope.

Democracy, though, is inadequate as a language and frame for left political aspiration. Here are two reasons why; there are others. First, the right speaks the language of democracy. It voices its goals and aspirations in democratic terms. One of the reasons given for the U.S. invasion of Iraq, for example, was the goal of bringing democracy to the Middle East. Similarly, leftists in the United States urge inclusion and participation, and so do those on the political right. The right complains about the exclusion of conservatives from the academy and God from politics. They, too, try to mobilize grass-root support and increase participation. There is nothing particularly left, then, about inclusion and participation. These are elements of democracy the right also supports. This rightwing adoption of democratic ideals prevents the left from 
occupying the position of a political alternative to the right—if left positions are the same right ones then the left isn't an alternative. Slavoj Zizek describes this situation where one’s enemy speaks one’s language as “victory in defeat” (2008, p. 189). When one's enemy accepts one's terms, one's point of critique and resistance is lost, subsumed. The dimension of antagonism (fundamental opposition) vanishes.

A second reason democracy is inadequate as an expression of left aspiration is that contemporary democratic language employs and reinforces the rhetoric of capitalism: free choice, liberty, satisfaction, communication, connection, diversity. Like any media savvy corporation, democratic activists want to ensure that voices are heard and opinions registered. Corporations and activists alike are united in their preoccupation with awareness: people need to be aware of issues, of products, of products as signs of issues. In this concrete sense, Zizek is right to claim that attachment to democracy is the form our attachment to capital takes (2002, p. 273; 2008, p. 184). In the consumption and entertainment-driven setting of the contemporary United States, one’s commitments to capitalism are expressed as commitments to democracy. They are the same way of life, the same daily practices of "aware-ing” oneself and expressing one's opinion, of choosing and voting and considering one's choice a vote and one's vote a choice.

More than inadequate as an expression of left political aspiration, democracy names left castration (“I know, but nevertheless”). Because the left presents itself as appealing to and supporting democracy, it fails to take a stand, to name an enemy. Instead of drawing a line and saying what it is against, what it excludes, left political theory in the contemporary United States advocates inclusion, universality, multiplicity, the plurality of modes of becoming, and ethical responsiveness. ${ }^{1}$ The dilemmas arising out of such advocacy have vexed left politics for some 
time now as the politically correct encounter situations where inclusion comes up against its limits. Politics embracing cultural diversity and progressive approaches to gender and sexuality do not fit easily together when what is taken to be a distinct culture rests on patriarchy or homophobia. Likewise, opposition to religious fundamentalism can rub up against secularizing projects of western imperialism. In such instances, an ideal of inclusivity is clearly inadequate: not every position is compatible with every other.

Left embrace of democracy denies democracy's limits. It wants to hide itself from the ways democracy necessarily depends on and requires exclusion. Insofar as left political theory adopts democracy as its primary aspiration, it disavows the fundamental antagonism conditioning politics as such. For the left (in the United States and in parts of the European Union), democracy thus takes the form of a fantasy of politics without politics (like fascism is a form of capitalism without capitalism): everyone and everything is included, respected, valued, and entitled. No one is made to feel uncomfortable. Everyone is heard and seen and recognized and has a place at the table (George Lakoff identifies Barak Obama as a key figure in the new politics, which is precisely this "politics" of unity, empathy, and understanding). ${ }^{2}$

The criticisms of left embrace of democracy I raise here are part of a broadly shared frustration with and on the contemporary left. Indeed, left complaining or whining might even be the primary mode of left theorizing today. We wallow in misery, in the deadlock in which we find ourselves. But whereas my emphasis is on democracy as the name of left deadlock, of the fantasy of politics without politics, others view the current problem as a crisis of dedemocratization (Wendy Brown) or de-politicization (Jacques Ranciere). As Ranciere makes clear in his writings from the nineties, elements of the depoliticization thesis resonate with mainstream political discussions of the end of ideology, the rise of consensus politics, and even 
the neoliberal withering away of the state, that is, the revisioning of the state as just another contractor of economic services—we were told that the era of big government was over. Financial crises that manifest themselves in the U.S. in 2008 and led to what the Bush administration presented as a necessary 700 billion dollar bailout of banks and institutions "too big to fail” quickly made this notion seem quaint and unconvincing. Nonetheless, the theme of depoliticization has been a pronounced one in the United States and Europe since the collapse of the Soviet Union. It makes sense, then, to consider this theme more closely, interrogating its suppositions and their applicability in the contemporary setting. If the diagnosis of dedemocraticization and de-politicization is correct, then left politics should seek more democracy, should attempt re-politicization. But if I am right about the contemporary democratic deadlock, then a politics that reasserts democracy as the solution to all our problems will continue to entrap us in the same old circuits of defeat. It will fail, moreover, to attend to the politicizations already conditioning the current conjuncture.

In On the Shores of Politics (originally published in French in 1992; English translation published in 1995), Ranciere offers a version of the end of ideology thesis that affiliates this end with a kind of triumph of democracy (a triumph he criticizes). Democracy, Ranciere writes, is "no longer perceived as the object of a choice but lived as an ambient milieu, as the natural habitat of postmodern individuality, no longer imposing struggles and sacrifices in sharp contradiction with the pleasures of the egalitarian age” (22). Such lived democracy is habitat rather than struggle; it is the setting in which we find ourselves rather a position requiring sacrifice and decision. As habitat, democracy is not itself political. Although this "becoming modest" of the state appears as a quintessentially modern adoption of the "same modes of management, communication, and consultation as the business enterprise” (106), 
depoliticization, Ranciere argues, is actually the "oldest task of politics” (19). Politics itself brings about depoliticization. Indeed, "politics is the art of suppressing the political” (11). Ranciere's arguments here are elegant and persuasive. They result, however, in an analysis that hinders our ability to think clearly about the current conjuncture. Ranciere accounts for the cause of depoliticization, politics itself, but he can't explain the specificity of the present combination of neoliberalism and democracy as ambient milieu. Contemporary depoliticization, then, is but another appearance of the same old problem of politics.

In Disagreement (published in French in 1995; English 1999), Ranciere attends to some of these specificities. He claims that "the state today legitimizes itself by declaring that politics is impossible" (110). The present is thus marked by more than politics’ paradoxical essencethe suppression of the political. It is characterized by the explicit acknowledgement of depoliticization as the contemporary state’s legitimizing ideal. Accordingly, Ranciere identifies several elements of contemporary post-politics as they confirm the impossibility of politics and hence legitimize the state: the spread of law, the generalization of expertise, and the practice of polling for opinion (112). Polling, for example, renders the people as "identical to the sum of its parts” (105). "Their count is always even and with nothing left over," he writes, “And this people absolutely equal to itself can always be broken down into its reality: its socioprofessional categories and its age brackets,” (105). It is worth nothing that Ranciere's emphasis on law repeats the "juridification" thesis Habermas offered already in the nineteen eighties. For Habermas, the problem was law's encroachment on the lifeworld. Excess regulation risked supplanting the communicative engagement of participants in socio-political interaction. For Ranciere, the problem is a legal resolution of conflict that forecloses the possibility of politicization. 
The arguments for post-politics and de-democratization are at best unconvincing and at worst misleading to a left seeking to undo thirty years of neoliberalization. The claim that we are in a post-political time, that politics has been foreclosed, excluded, prevented from emerging, is childishly petulant. It's like the left is saying, “if we don't get to play what we want, we're not going to play.” The failure of left politics to win, or even score, is equated with a failure of politics as such, rather than acknowledged in the specificity of left defeat. Leftists assume that our lack of good ideas means the end of the political. If the game isn't played on our terms, we aren’t going to play at all. We aren’t even going to recognize that a game is being played. To this extent, the claim for post-politics erases its own standpoint of enunciation. Why refer to a formation as post-political if one does not have political grounds for doing so? If one already has such grounds, then how exactly is the situation post-political? If one lacks them, then what is the purpose of the claim if not to draw attention to or figure this lack for the sake of political struggle?

Given the successes of the right, moreover, the claim that we live in a post-political time doesn't ring true. In the United States, the right has worked actively to reframe the constitution according to a theory of the unitary executive, to reverse the steps taken toward racial equality by undercutting Brown v. the Board of Education, to facilitate the redistribution of wealth to the top one percent of the population, to undermine the Geneva conventions as well as habeas corpus, to empower unwarranted state surveillance of the population, and to install a narrow, extreme, version of fundamentalist Christian doctrine into scientific discussions of evolution and climate change so as to disable any supposition of a common world or reality for which we might share responsibility. These are political achievements. To emphasize post-politics prevents us from understanding them as such. 
Far from affirming the identity of the people with itself, as Ranciere argues, contemporary polls reveal a fundamental split, a fundamental uncertainty, and the excess of politics over attempts to identify the people with "the calculations of a science of the population’s opinions” (Disagreement, 105). Since the 2000 U.S. Presidential election, ultimately decide by the U.S. Supreme Court, conventional wisdom has affirmed a divide between red and blue states. Polls reveal this split. They express not indecision or variance among groups understood as parts of a whole but instead a fundamental division. Former President Bill Clinton's quip following the election to the effect that "the people have spoken; we just don't know what they said" is thus misleading. What was clearly spoken was the division in the country. Likewise, polls taken daily, even hourly, during the long U.S. presidential campaign of 2008 differ from each other; consumers of political news ingest numbers that differ from each other, call each other into doubt, and render the very categories of polling unstable. The gap between polls and electoral outcomes, the failure of exit polls accurately to predict the votes tallied (an issue in both the 2000 and the 2004 elections), and the politicization of this gap as corruption, crime, theft, and the racist disenfranchisement of African-American voters express a politics irreducible to the "postdemocratic metapolitics" Ranciere associates with the triumph of consensus.

While it may well have been a compelling account of France in the nineteen nineties, Ranciere's version of post-politics is inapplicable to the United States post 9/11. From the present vantage point, Ranciere's critique of the spread of law as a primary form of depoliticization appears as a neoliberal argument against governmental oversight and for privatization. Not only does it fail to acknowledge the collapse of regulation in the financial sector, but it also occludes forms of public/private partnership, the rise of private security forces, 
and contemporary practices of surveillance wherein state agencies rely on private databases. Ranciere's dismissal of law, administration, and expertise thus cannot serve as a basis for a critique of the neoliberal state's abolition of oversight and neglect of basic governance. I should add that it is also incompatible with the acknowledgement of the widespread skepticism toward science and expertise and the concomitant cultivation and embrace of amateur, ordinary, and common opinion, a phenomenon Zizek associates with a general decline in symbolic efficiency (1999, 322). Over the last decade, the United States has witnessed the supplanting of expert knowledge by gut instinct, by religious faith, by capacities to know simply by seeing or feeling, and by the rejection of detail and complexity as elitist, unnecessary, and unwarranted. In this setting, techno-legal regulation and administration would be an improvement.

Nonetheless, there are two ways that post-politics is a useful descriptor. Post-politics names a specific problem in left political theory: the fantasy of a politics without politics. Such a fantasy animates Michael Hardt’s and Antonio Negri’s multitude as well as Giorgio Agamben’s coming community. It appears as well in the U.S. left's embrace of new social movements and identity politics. Understood in terms of the fantasy of a politics without politics, the problem of post-politics then becomes not one of governance, not one of consensus politics and opinion polls, but rather one linked to the left embrace of identity as the primary term and terrain of political struggle. In accepting an empirical account of identities (an acceptance we can date to the nineteen eighties and nineties), left endeavors toward inclusion and recognition ended up naturalizing rather than politicizing markers of identity. We treated identities as sociological rather than political categories and hence as unable to figure universal claims. For example, a term like "people of color” fails to function as a universal but designates instead exclusion from the category "white.” It works sociologically as an empirical description rather than politically as 
a claim to universality. To be clear, this failure of identity categories to function politically is not always and everywhere the case. It is not a necessary outcome of identity politics. Nonetheless, it is widespread and it works against the building and invigorating of a contemporary left.

A second way the concept of post-politics can be useful is as an accentuation of the depoliticization of democracy. In the current conjuncture, to argue for democracy is to argue for more of the same. It is vehemently to demand what is already present, accepted, agreed on. To appeal to democracy is to appeal to the process in place. To this extent, democracy does not establish another stage (to use Ranciere's formulation for disrupting a particular regime of appearance). It does not open onto the universal or mobilize a segment of society as society. Such mobilization was possible when democracy named an opposition, whether to oligarchy or absolutism or fascism or colonialism. In these instances, to stand for democracy was to stand against another order constituted against democracy. These days, though, when right and left agree on democracy, when democracy is the underlying supposition, when it provides the basic vocabulary of law and politics, to emphasize democracy is simply to invoke our "ambient milieu," to try to have politics without politics.

Before proceeding, I should acknowledge my uncertainty regarding my lack of confidence in democracy. Perhaps my doubts stem from the wrong concept of democracy. Or perhaps they oscillate between concepts, ultimately relying on no concept whatsoever. There are at least three sites a theory of democracy might designate:

a. democracy might designate a site of resistance, struggle or opposition;

b. $\quad$ democracy might designate a system of governance, order, or rule;

c. democracy might designate a society, culture, or spirit (ambient milieu). 
Which of these three is correct? Derrideans would say the fourth one: democracy is always to come and hence necessarily exceeds the three aforementioned sites. But this answer is just another version of “I know but nevertheless.” Democracy remains an ideological fantasy covering the failures, excesses, and obscenities of real existing democracy. The Derridean response thus returns me back to where I started: democracy as the solution to the problems of democracy or the democratic capture of left aspirations to equitable and sustainable distributions of resources, labor, and its products.

Derridean democracy to come and the post-politics, post-democracy thesis are two sides of the same coin. They are two aspects of democratic time, past and or future, but not now (Zizek might say that their relation is that of a parallax; we can see democracy from each perspective but not from the two perspectives simultaneously). Consider a chant repeated at hundreds and thousands of protests over the last decade: What do we want? Democracy! When do we want it? Now! This chant works as a protest because it is clearly impossible. What would happen if the response were “Okay, protestors, you've got your democracy. Now what are you going to do?” Imagine the executive branch of the U.S. government walking off the job, handing their codes and files and top-secret stamps to the throngs outside their gates, the protestors wondering what to do with their puppets, signs, and bongos as they fragment into affinity groups and try to decide what their goals and priorities are. The protestors are not really demanding democracy now. Their demand is not meant to be met. ${ }^{3}$

Democracy has already arrived — as language of right and left, governance and electoral politics, ambient milieu. This is what democracy looks like, real existing democracy. To avoid the trauma of the real, of getting what we wished for, leftists move from actuality to possibility 
(from what we have to what could be), a move, incidentally, perpetually denied socialist critics of real existing socialism.

But this move from actual to possible democracy doesn’t quite work. It misses its own movement or moving, the torsion that the shift from actual to possible entails. Zizek's description of the temporal anamorphosis (distortion) of objet petit $a$ is appropriate here:

Spatially, $a$ is an object whose proper contours are discernible only if we glimpse it askance; it is forever indiscernible to the straightforward look. Temporally, it is an object which exists only qua anticipated or lost, only in the modality of not-yet or not-anymore, never in the 'now' of a pure, undivided present $(1993,156)$.

This description applies to democracy. Democracy is anticipated or lost, but never present. When one looks at the present, all one sees is a gap, perhaps manifested by multiple attempts to fill it, as in the various definitions of democracy as resistance, governance, or ambient milieu. There can be past democratic ideals—nostalgic fantasies of Athens, town meetings, our days in the resistance-or there can be hope for the future, justification of present acts in terms of this future, but there isn’t responsibility now. So disavowing democracy’s arrival, democracy now, contemporary left fantasies of democracy animate its diagnoses of post-politics and inspire its rejections of law, regulation, and the state.

In the account I've offered thus far, democracy appears as an obscure object-cause of desire, something that can never be fully attained or reached without ending the desire for it. But this is only one aspect of objet $a$. The other is its status in drive, not as something lost but as a hole or gap, not as an impossible lost object but as loss itself. Drawing from Lacan, Zizek construes drive as fixation, not as the thing onto which one is fixated (2006, 62). In drive, enjoyment comes from missing one's goal, from the repeated yet ever failing efforts to reach it 
that start to become satisfying on their own. Drive circulates around an object, generating satisfaction through this very circulation. Perhaps paradoxically, then, drive is at the same time disruptive. Fixation cuts into and derails the regular course of things, what is taken for the conventional patterns of everyday life, assessments of benefit and risk, pragmatic realism, and the organic attempts to secure the conditions of life. It's a traumatic kernel in the reality of the symbolic order itself.

This drive dimension better describes democracy for the left; it is our circling around, our missing of a goal, and the satisfaction we attain through this missing. It accounts for the attachments and repetitions to which we are stuck, even as this very stuckness undermines our possibilities for political efficacy. Democratic drive, then, is another way of conceiving democracy as ambient milieu, a way that highlights the circulation we can't avoid, but which at the same time can't be understood as giving us what we want even as it gives us something else instead, some kick of enjoyment. We protest. We talk. We complain. We undercut our every assertion, criticizing its exclusivity, partiality, and fallibility in advance as if some kind of purity were possible, as if we could avoid getting our hands dirty. We sign petitions and forward them to everyone in our mailbox, fetishizing communication technologies as the solution to our problems. We worry about conservatives even as we revel in our superiority-how can anyone be so stupid? We enjoy.

If drive involves circling around and fixating on a loss, hole, or gap, how should the hole around which democracy circulates be understood? For it is neither the empty place of power, nor a missing and impossible unity, nor a master signifier ready to be articulated into a signifying chain, conceptions that all rely on a logic of desire. In Disagreement, Ranciere considers the beginnings of politics in terms of "an original twist that short-circuits the natural logic of 
'properties'” (13). This twist, torsion, or interrupted current, he argues, is the wrong of a fundamental dispute that causes politics to occur. The smooth space of the natural order confronts a gap or hole. So there is not a natural order but a twisted one. There is a not a smooth flow or set of natural relations and identities; there is a hole distorting the whole, belying the fiction or fantasy of the whole thing or order.

The hole of this original torsion is a missing conjunction, a missing link between people and government that political theory tries at best to express and at worst to occlude (government of the people, by the people, for the people, over the people). The torsion of politics means that the people and the government are not present at the same time (even Rousseau had to gloss his fantasy of the unrepresentable sovereignty of the people with a nod to Corsica). Where the people are present, there is chaos, disruption. Where government is present, then the people are not. Insofar as the people can never be fully present—-some don't show up, didn't hear what was going on, were mislead by a powerful speaker, were miscounted from the outset—-their necessary absence is the gap of politics.

The torsion of wrong, Ranciere adds, makes each class different from itself (Disagreement, 18). A class doesn’t simply persist doing its part in a larger complete whole. Political groups such as classes are not functional components of a prior order, an assumption as depoliticizing as it is foundational to political theory. Insofar as they are split within the whole and within themselves, the many cannot be politically. Polls try to make them appear through a count, which is always a kind of miscount and distortion. The many, though, is only political through and as one, few, or some: one represents us to ourselves as many; few make possible and organize, provide themes and ideas; some do all the work (business types present this as the 80/20 rule). The people are always non-all, not simply because the many is open and incomplete 
but because it cannot totalize itself. The rule of a leader, party, or even the law compensates for or occupies the hole of the missing conjunction between people and government (Zizek 2002, pp. 187-189).

Hence Ranciere in Disagreement separates political activity into two parts, two opposed yet entangled logics of politics and the police (28). We might think of these two parts as a division between legitimacy and order; each has what the other needs and/or wants, something that remains inaccessible, out of reach, something that would destruct if attained. To split politics into itself and the police is a way of saying there is no pure politics; there is more than upheaval; there is rule and ruling requires limits. In Ranciere’s terms “politics acts on the police” (33).

Zizek adds the insight that cutting through both aspects of politics is the difference between rule and its obscene supplement, the difference between the letter of the law and the shadowy, nightly law on which it rests (1999, pp. 234-235). We invoke this obscene dimension when we speak of dirty politics, dirty tricks, and dirty cops, of those who are willing to get their hands dirty. Zizek refers to the famous line from Saint-Just: "nobody can rule innocently” (1993, p. 221). This is another way of saying that there is no pure politics, no innocent position. Politics' primal scene, as it were, is its confrontation with compromise, failure, exclusion, the means necessary to get things done.

Different discursive formations provide the fantasies occluding (and securing) this obscene fact. The master's version: there is one who can rule innocently. Fantasies of the master forever seek to find this One. The democratic response replaces the one with all (as if such an all were possible without its constitutive exclusion): everybody can rule innocently. The perverse response: I'm willing to make myself into an instrument of the dirty work. Ranciere has yet 
another response. He fully accepts that there is no innocent position (this is his notion of the police) but adds that this not a problem because anybody can rule.

That anybody, anybody at all, can rule is, for Ranciere, the scandal of democracy. Democracy is the scandalous actuality of the contingency of the political. Via Zizek, I understand "contingent" to describe something that cannot be wholly grounded in its conditions of possibility $(1993,157)$. That which is contingent is possible; it could have been otherwise. Possibility, though, is not the same as contingency: what happens contingently could have not happened although it did. But why does Ranciere associate contingency with democracy? Why is democracy another word for the contingency of the political? In the remainder of this paper, I take up this question of contingency, focusing on changes in Ranciere's discussions of politics and equality from On the Shores of Politics to Disagreement. My interest here is in the way Ranciere's arguments provide insight into the failure of democracy as a political form. Politics exceeds its narrative capture in and as democracy. As he attempts to equate politics and democracy, Ranciere brings to expression the deadlock of democratic drive.

II.

I've presented post-politics and democracy-to-come as two sides of the same coin. I've suggested that the gap separating and connecting them be thought in terms of the closed circuit of drive rather than the openness of desire. So understood, democracy is not what we seek but never reach, not a name for political desire as such, but instead a term for the capture of political aspiration in the circuit of drive. Democracy is a remnant from the nineteenth and twentieth centuries we have yet to escape. Differently put, if democracy names a political desire that is 
never fulfilled, then it is accompanied by a political drive wherein democracy is what we fail to escape. In this dimension of drive, democracy designates our political stuckness.

In On the Shores of Politics, Ranciere presents politics as the depoliticizing response to democracy and equality as the counterfactual supposition to be repeatedly inscribed in and on the community. There is politics, he argues, because there is democracy. Politics responds to democracy. Understanding why requires the introduction of the notion of equality. Ranciere construes equality in terms of the creation of a space of appearance: "the egalitarian polemic invents an insubstantial community completely determined by the contingency and resolve of its enactment” (87). In the setting of material hierarchy, of a factual inequality wherein the few have much and the many have little, a claim to equality is spoken; it is contingently and forcibly introduced into the setting. Equality is posited and with it the demand that inequality be explained. This egalitarian polemic enables the people to appear, not as an actually existing empirical group but as a supposition of reason and community. It contrasts with the facts of actual inequality and produces a shared rationality by effecting a division between how things appear and how they can be made, forcibly, to appear. The postulation of a shared meaning, Ranciere argues, “assumes a symbolic violence both in respect of the other and in respect of oneself” (49). Politics results from this specifically democratic mobilization of appearance. It responds to the inscription of equality into facticity by trying to suppress it.

In Disagreement, Ranciere changes this formulation of politics as a depoliticizing response to equality as he focuses on the confrontation equality stages. The opposition between democracy and politics becomes an opposition between politics (understood as democratic) and the police. Politics is no longer the force of depoliticization; rather, it is an activity antagonistic to policing (the other side of the antagonism constitutive of the political). 
I read the opposition Ranciere introduces in Disagreement as internal to the political, as a division within politics between two perspectives linked by the gap between them (a parallax gap wherein the same object appears slightly different when looked at from the perspective of each division). Politics, then, is the manifestation of this gap or division. Examples of the division between politics and the police in the history of political thought appear as divisions between legislation and execution, between constituent and constituted power, and between the people as sovereign and as subject. In Ranciere's version, politics occurs in the meet-up between two heterogeneous processes - the process of the police and the process of equality. The police is "an order of bodies that defines the allocation of ways of doing, ways of being, and ways of saying ... it is an order of the visible and the sayable” (29). Ranciere uses the term politics to designate "whatever breaks with the tangible configuration whereby parties and parts or lack of them are defined by a presupposition that, by definition, has no place in that configuration- that of the part of those who have no part” (29-30).

Each aspect of political activity, politics and police, makes something appear. Politicsthrough the egalitarian inscription—-disorders appearance, making something appear different from the way it appeared before. As an ordering or arranging, a counting, an assigning of place, the police, too, makes something appear differently. The clash of politics in the gap and confrontation of two heterogeneous logics, then, is a clash not between how things are in reality or between reality and appearance, but in their modes of appearance or representation.

The part of no part thus does not designate the objectivity of an empirical group excluded from the political domain. It's not another way of referring to a politics of identity by locating a marginalized other. For Ranciere, political subjectification is not political identification, rather it is the inscription of a name, a disidentification and the registration of a gap (Disagreement, 36). 
He explains that there are "political modes of subjectification only in the set or relationships that the we and the name maintain with the set of 'persons,' the concrete play of identities and alterities implicated in the demonstration and the worlds—common or separate- where these are defined” (59). Political subjectification stages polemical scenes, paradoxical scenes that bring out the contradiction between two logics. Indeed, it stages the very contradiction between police logic and political logic (41). This contradiction is thus internal to politics; it is politics. Accordingly, it makes most sense to think of the part that is not a part as precisely such a gap: a gap in the existing order of appearance between that order and other possible arrangements, the space between and within worlds. The Lacanian term for the part of no part would then be objet petit $a$, an impossible, formal object produced as the excess of a process or relation, a kind of gap that incites or annoys, the missingness or not-quite-rightness that calls out to us.

A benefit of considering the part of no part as objet $a$ is its accentuation of the fact that this part is not a substantial part, not an empirical designator such that exclusion is the exclusion of people and their inclusion necessarily a political good. For example, religious fundamentalist might be a name of the part with no part in a liberal order. To include that part would distort and disrupt the order predicated on the exclusion of fundamentalist religion. Moreover, if one views the contemporary political terrain as a global one, as constituted through the elimination or subsumption of an outside (Hardt and Negri's view), then understanding the part of no part as objet $a$ can enable the theorization of the holes and gaps constitutive of the shape this global terrain takes. Finally, to treat the part of no part as objet a brings out the fact that the democratic narrativization of the gap or torsion of politics is but one possible narration. There are others, others that might and should be rejected or accepted but that will continue to incite, annoy, 
thwart, and produce us. Acknowledging these torsions will not make them go away. But it might enable us better to comprehend and tactically address ways that we enjoy being politically stuck. I've argued that the part of no part be understood as objet $a$ and that the division between politics and the police be read as an internal division within politics. If this division is not internal to politics, then Ranciere’s position falls into a kind of hysterical pure politics of resistance (cf. Zizek's critique in The Ticklish Subject). Much of his discussion in Disagreement suggests such a pure politics, particularly insofar as Ranciere insists that politics is essentially democratic and that it is democratic because it consists in the confrontation between the police logic and egalitarian logic. For example, he views politics has happening "very little or rarely," only when the mechanisms of majesty and management are "stopped in their tracks by the effect of a presupposition that is totally foreign to them yet without which none of them could ultimately function: the presupposition of the equality of anyone and everyone, or the paradoxical effectiveness of the sheer contingency of any order” (17). I turn, then, to Ranciere's account of equality and its association with contingency.

As I have already mentioned, in On the Shores of Politics, the inscription of the egalitarian signifier into a factual situation makes the "community of equals appear as the ultimate underpinning of the distribution of institutions and obligations” (91). The declaration of equality makes the artifice of power visible as such. It makes a given arrangement of power appear as contingent, unnecessary, as something that has been created and could be otherwise. Disagreement develops this contingent dimension of equality such that equality means the sheer contingency of social order. Ranciere describes the empty freedom the Athenians presented to philosophy as "the equality of anyone at all with anyone else: in other words, in the final analysis, the absence of arkhe, the sheer contingency of any social order” (15). What is given 
isn't necessary; it didn't have to be this way. It could have been otherwise. Politics occurs when a given order of the police (or partition of the perceptible) is confronted with its own contingency.

Ranciere’s emphasis on contingency is not convincing on its own (without an accompanying discussion of possibility and necessity). It's more akin to a fantasy. Like Cinderella, I could really be a princess! I coulda been a contender, a rock star. I still could! Zizek argues that fantasy, "in its most basic dimension, implies the choice of thought at the expense of being: in fantasy I find myself reduced to the evanescent point of a thought contemplating the course of events during my absence,” (1993, p. 64). What Ranciere presents as contingency is a fantasy that holds out the possibility of "anything at all” as a way of accommodating a situation without confronting the reality of the constraints in producing it, the determinations of socio-economic systems and practices. Such a fantasy is ultimately a fantasy of my own non-existence in the situation I confront, as if somehow I was outside of and apart from the situation's determinations. Leaving aside the historical question of whether democracy in Athens really meant that anyone could rule, anyone at all—-the determinations of gender and slavery suggest otherwise-a reading of politics as rooted only in its own contingency is too close to a state of nature or view from nowhere to be useful for thinking through the challenges of contemporary politics. What possibilities does a given actualization abandon or even foreclose? Simply to say that such an actualization was contingent rather than necessary neglects this question and obscures the persistence of necessity under the fantasy of what could have happened.

The claim that the situation could have been different fails to provide leverage toward making the situation different. Few today argue that our arrangements and institutions are 
natural or inevitable. For example, social conservatives in the United States readily accept that the family is a social construct and a fragile one at that. Hence, they offer policies designed to shore up a specific patriarchal vision of the nuclear family. They don't think sexual identity is fixed; thus, they sponsor programs that try to make gay people straight. When democracy is our ambient milieu, contingency's revelation of artifice, of the fact that things might be otherwise, loses any efficacy it might have had in setting where order was justified as natural.

More troubling, though, is Ranciere’s rendering of contingency specifically as equality. Ranciere's idea is that insofar as the political order is not given by nature, not determined, it rests on an underlying contingency; its foundation is its lack of foundation (Disagreement, 16). Politics occurs as an interruption, the interruption of a freedom that "makes real the ultimate equality on which society rests” (16). The question, then, is the status of this equality. A foundation in equality is not the same as the contingency of inequality; underlying a contingent inequality could well be multiple contingent inequalities or the possibility of equality. Ranciere seems to be saying that something about equality is Real, more than an inscription and the production of a common space of disagreement. He suggests, in order words, that equality is not only an aspect of the symbolic order but also a distorting of or gap within that order. When equality appears it appears within the order of the police. Politics forces it to appear and so changes this order, but the appearing remains within the order of the police. The order of the police is a condition for equality’s appearance.

Ranciere describes the equality he has in mind as that of any speaking being with any other speaking being. The logic of equality, he says, is a logic that dispels the count and distribution of the order of the police; it "disrupts this harmony through the mere fact of achieving the contingency of the equality, neither arithmetical or geometric, of any speaking 
being whatsoever" (Disagreement, 28). Not surprisingly given this supposition of communicative competence on the part of speaking beings, Ranciere considers the necessary suppositions of understanding in language. His account differs from Habermas's primarily on the matter of consensus (Disagreement has an extended critique of Habermas on a number of grounds including Habermas's distinction between poetic and argumentative language, his shift away from a third person perspective, and his account of performative contradiction). For Habermas the supposition of understanding means that we have to suppose an orientation to agreement. Ranciere disagrees. He argues that understanding is rooted in a supposition of equality and this supposition leads to disagreement.

Consider a command. To follow a command, the commanded must comprehend what the command is and understand that the command is meant to be followed or observed. The implication of this supposition of understanding, Ranciere tells us, is that even hierarchy is premised on an underlying equality. He writes: "equality is an assumption that another understands what I'm saying” (Disagreement, 33). In the setting of what Zizek tags the decline of symbolic efficiency, this assumption of understanding is rather far-fetched. Our present political-medialogical setting is one of dissensus, incredulity, and competing conceptions of reality. Most of the time it seems like no one understands much of anything anyone says. As Žižek points out, Donald Davidson designates the background assumption that everything another says is not completely wrong the "principle of charity." It's a presumption of underlying agreement on which disagreement rests. Davidson argues that "charity is not an option...charity is forced on us; whether we like it or not, if we want to understand others, we must count them right in most matters" (cited in Zizek 2000, p. 114). The decline of symbolic efficiency points to the withering away of this principle of charity: less and less are people today forced to presume 
charity or understanding. There are strong material-technological explanations for this withering away. Not only are communication technologies charitable in our stead, making connections with other machines, but the interconnecting of ever more people lets us find enough of those who share our convictions that we don’t have to believe. In fact, we can imagine a contemporary post-linguistic argument to the effect that equality is the assumption that nobody understands what anyone else is saying, an assumption of shared incomprehension (but an incomprehension that connects nonetheless), a kind of incommensurability that morphs into its opposite. Insofar as equality can be just as easily viewed in terms of incomprehension as it can be viewed as a supposition of understanding or principle of charity, Ranciere’s argument for equality is unconvincing.

Nonetheless, what is important for Ranciere is the equality that underpins understanding. He explains:

To say that there is a common speech situation because an inferior understands what a superior is saying means that a disagreement, a provisional confrontation must be set up between two camps: those for whom there is an understanding within understanding, that is, that all speaking beings are equal speaking beings, and those who do not think so. The paradox is that those who think there is an understanding within understanding are for that very reason unable to take this deduction any further except in the form of a disagreement, since they are bound to show a result that is not at all apparent (Disagreement, 49).

Ranciere's argument is a nice twist on the idea of performative contradiction (and I have in mind here Habermas's use of this idea). Typically, the idea of a performative contradiction emphasizes an incompatibility between the content of an utterance and the conditions that make its uttering 
possible (Lacan discusses this as a difference between the enunciation and the enunciated). In introducing the performative contradiction, one forces the speaker to consider what she has to assume not just to make her point but to speak at all. Ranciere’s version of this idea employs a response to the claim of performative contradiction that says, "So what? I still disagree," (a response that drives Habermasians crazy). He highlights the side of the one accused of contradicting herself (her conditions of speech), attributing to her an obstinacy or resistance in the face of full awareness of contradiction. This obstinacy, moreover, is what sets politics in motion. The stand-off makes politics necessary.

More specifically, then, Ranciere takes the fact of understanding and says that from this fact one can assume that speaking beings are equal or one can assume that speaking beings are unequal. Those who insist that speaking beings are equal cannot rely on logic or reason to persuade their opponent (who doesn’t accept them as equal). But their insistence can nonetheless stage the disagreement between them and their opponent; it can make the division between them appear. The one who asserts that understanding means that speaking beings are equal has to prove what is not apparent. He has to demonstrate what does not appear to be the case. He has to make equality appear in a setting of apparent inequality. The stage of political conflict, then, is constituted through positing an equality of speaking beings in a setting of inequality, through making this common stage appear via disagreement. Ranciere's example is the worker who proceeds counterfactually as if there were a shared world of argument, even though there is not one, even though the owner of capital does not recognize or does not want to recognize this common world.

So politics appears through the disagreement of speaking beings, through a clash or gap produced in the encounter between their worlds and their words, a clash Ranciere describes as a 
staging of the contradiction between the egalitarian logic and the logic of the police. The assertion of egalitarian logic is contingent; one might assert equality or one might not. But here’s the rub: disagreement is what makes the stage of political conflict appear. Equality is one contingent vehicle for disagreement. Equality can serve as such a vehicle because it is counter to the conditions in which it is claimed (hierarchical conditions); hierarchy, however, is only one potentially politicizable condition of a given participation of the perceptible. The Real attached to equality, then, is the gap, missingness, or not-quite-rightness that the claim to equality makes apparent; it's the Real of a disjuncture. More precisely, objet a attaches to equality as the gaze that perceives the gap effected by the distortion of the Real (cf. Zizek 1993, p. 66).

Ranciere's emphasis is on the disgreement between those who claim the equality of speaking beings and those who deny it. Such disagreement is not essential to equality but can be made to appear through other counter-factual claims. We can imagine the inscription of liberty as a claim to freedom in conditions of unfreedom; or the converse: a claim of unfreedom in conditions of freedom. One says an unfettered market in commodities is freedom. The other responds: I disagree. We can imagine the inscription of ownership in the commons, a claim to private property in conditions of common goods. One says: this is mine. The other responds: I disagree. And we can imagine claims of belonging in conditions of fear and exclusion. The one says: I am one of you. The other says: I disagree. Each of these instances of liberty, ownership, and belonging stages a conflict within a given partition of the perceptible and attempts to make an alternative partition appear. But none is the same as the egalitarian inscription and none is strictly speaking democratic. There are non-democratic stagings of disagreement. And because there are non-democratic stagings, politics is not necessarily democratic. 
In fact, more problematic than Ranciere's reduction of politics to the clash between the egalitarian logic and the logic of the police is a further entanglement that the instances of liberty, ownership, and belonging highlight, namely, the implication that the police is necessarily counter to democracy and democracy necessarily counter to the police. The order of the police may well involve a rule of law that seeks to preserve and protect certain liberties, common or public spaces, and practices of belonging. Contesting this order can involve taking the position of the part of no part and making the violence and contingency of the order's partition of the perceptible appear. Insofar as such contestation is contingent, its effects are neither necessary nor necessarily democratic. Again, we might think here of instances of a fundamentalist (whether religious, ethnic, or market) rejection of its democratic foreclosure; the fundamentalist occupies the place of what a democratic partitioning must exclude and makes this exclusion appear in its contingency and violence.

If the dominant order presents itself as democratic, if the order of the police is the order of democracy, then only non-democratic stagings of disagreement can be political since only they set up a contrast with the conditions of their utterance. Far from exclusively democratic, politics can be fascist, anarchist, imperial, communist. Such stagings are holes, gaps, torsions in the contemporary setting, sites that annoy and excite. Ranciere narrativizes the introduction of gaps as necessarily democratic and laments the contemporary post-political conditions of impossibility for their emergence. My argument is that gaps emerge; they are political, and contemporary democracy organizes enjoyment as an effect of circling around these gaps. Ranciere's narrativization, then, is better understood an image of the capture of politics in the circuits of democratic drive. The contemporary setting is not one of simple opposition between post-political consensus and the eruption of irrational violence (and eruption Ranciere views as a 
return of the archaic). Rather, it involves the satisfaction of the democratic drive as its aims remain inhibited.

A consideration of the gaze may help clarify my idea here. Ranciere emphasizes the way the disagreement over the equality of speaking beings stages a conflict and enables the appearance of the contingency of the prior partition of the perceptible. Disagreement depends on a prior thwarting of the aim, equality. Rather than achieving the goal of equality, then, disagreement produces satisfaction, I'll call it a political satisfaction, by staging the lack of equality. Although it might seem paradoxical that one's aim is not agreement to one’s demandthe demand for equality — the paradox occurs only in the register of desire. Understood in terms of drive, the bending or distortion or change in the aim such that the failure to reach it provides enjoyment makes sense. The aim of equality is sublimated in the drive to make one's disagreement with inequality appear. One gets satisfaction by appearing in one's disagreement. This provides its own partial enjoyment and in fact can only continue to provide it so long as there is inequality, so long as the ostensible aim in staging the disagreement isn't reached.

Ranciere's account of the staging of disagreement, rather than figuring the political as such (the political confrontation between politics and the police) exemplifies the sublimation of politics in democratic drive. As drive, democracy organizes enjoyment via a multiplicity of stagings, of making oneself visible in one’s lack. Contemporary protests in the United States, whether as marches, vigils, Facebook pages, or internet petitions aim at visibility, awareness, being seen. They don’t aim at taking power. Our politics is one of endless attempts to make ourselves seen. It's as if instead of looking at our opponents and working out ways to defeat them, we get off on imagining them looking at us. And since, as Lacan reminds us in Seminar XI, the object of the drive is of total indifference (1998, p. 168), the disagreement one imagines 
oneself being seen as staging is irrelevant. Egalitarian or elite, anarchist or communist, any political gap will provide a charge sublimated as it is within the democratic drive. We want to make ourselves seen as political without actually taking the risk of politics.

\section{References}

Lacan, Jacques. (1998) The Seminar of Jacques Lacan. Book XI. The Four Fundamental Concepts of Psychoanalysis, ed. Jacques-Alain Miller; trans. Alan Sheridan. New York: Norton.

Ranciere, Jacques. (1995) On the Shores of Politics, trans. Liz Heron. London: Verso. Ranciere, Jacques. (1999) Disagreement, trans. Julie Rose. Minneapolis: University of Minnesota Press.

Zizek, Slavoj. (1993) Tarrying with the Negative. Durham, NC: Duke University Press.

Zizek, Slavoj. (1999) The Ticklish Subject. London: Verso.

Zizek, Slavoj. (2000) The Fragile Absolute. London: Verso.

Zizek, Slavoj, (2002) Revolution at the Gates. London: Verso.

Zizek, Slavoj. (2006) The Parallax View. Cambridge, MA: The MIT Press.

Zizek, Slavoj. (2008) In Defense of Lost Causes. London: Verso.

1 Hence the signifying importance of the Holocaust as the exception, the one undeniable thing that must be clearly condemned. Of course, even this seemingly clear instance of "that which must be condemned" can be and is increasingly becoming cloudy as with movements 
toward acknowledging the suffering of the German people during the war or in Hollywood films that consider the "good Nazis."

2. George Lakoff, “Much More Than Race: What Makes a Speech Great,” posted to Open Left on March 24, 2008. Available at http://www.openleft.com/showDiary.do?diaryId=4751.

3. A reader on my blog counter with the claim that "this is what democracy looks like" is a more common protest chant. He argues that this is an assertion of a present democracy as disruption. I disagree. In the U.S. protests are not disruptive in the least. They are occasions for families to march together, for vendors to supply t-shirts and bumper stickers, for cops to photograph activist groups. They are licit and momentary, guarantees and supports of the system they ostensibly contest. 